\title{
Research on Frost's Poetry in the Light of Spiritual Ideology
}

\author{
LIU Yang ${ }^{1, a}$ \\ ${ }^{1}$ Qiqihar Medical University, Qiqihar 161006,China \\ aliuyang@126.com
}

Keywords: Robert Frost, natural poems, spiritual ideology, meaning of life

Abstract. Robert Frost is one of the world-widely known and highly esteemed American poets in the twentieth century. Frost used the traditional writing style in his poems to show his meticulous observation and contemplation of natural phenomena and laws of nature and life phenomenon of realistic problems. In-depth understanding of the preference for natural creation of the poet's view of nature is of important literature and practical significance, because Frost's view of life, like his natural poems is the valuable wealth that he gave us. This article mainly analyzes Frost's poetry in the light of spiritual ideology, contains "Discover the beauty of life", "Relationship between people" and "Ideology to Live the Life". Through unearthing the mean ideas embedded in Frost's poetry, I hope to inspire us to better understand nature and the meaning of life in modern life.

\section{Introduction}

Robert Frost, one of the most celebrated American modern poets, had enjoyed enormous popularity, wide readership and unusual honors like winning the Pulitzer Prize four times, receiving honorary degrees from forty-four colleges and universities, being invited to read "The Gift Outright" at the inauguration of President John F. Kennedy in 1961 and being crowned the nation's unofficial Poet Laureate.

Robert Frost was born in San Francisco, on March 26, 1874. His father William Prescott Jr. was a city editor of the San Francisco Daily Evening. His mother Isabelle Moodie was a conscientious teacher who had forceful educational influence on him. She always read loudly to him from Emerson, Shakespeare, Poe, the Bible, classical myths and romantic poetry[1,2].

For Frost's whole life time, he published ten volumes of poetry which contained 439 poems, along with 3 plays, and lots of prose and letters. These ten volumes were published between1913 and 1947: A Boy's Will (1913), North of Boston (1914), Mountain Interval (1916), New Hampshire (1923), West-Running Brook (1928), A Further Range (1936), A Witness Tree (1942), A Masque of Reason (1945), Steeple Bush (1947), and A Masque of Mercy (1947). In addition, two volumes of Collected Poems were published by Henry Holt in 1930 and 1939. Complete Poems of Robert Frost 1949 (1949) collected Frost's ten previously published volumes of new poetry, along with three new poems contained in a section titled "An Afterword". Richard Poirier and Mark Richardson edited the volume of Robert Frost Collected Poems, Prose, \& Plays in 1995[3].

\section{The spirit of Frost's poems}

Modern ecology research focuses on the human spiritual world, believe that the spirit is an important variable of the earth ecosystem, apart from the hydrosphere, pedosphere, lithosphere, atmosphere, biosphere and there should be a "spirit ecology" of belief, ideal, imagination, reflection, inspiration. This "spirit ecology" is the spirit of human ecology, it has to do with natural ecology and social ecology together to constitute the complete ecosystem on the earth. Good mental ecology refers to a kind of balance, stability and harmony of human spirit and the state of harmony, and it has important influence on the other two aspects of ecological system.

Frost underneath is a philosophical pastoral poet, but the natural poems are just tools that he used to explore the nature and meaning of life. He put the countryside as the background of poetry, but not limited to the narrow scope of the description of landscape and pastoral farming activity. He may described how he stepped on a nail rake and the pain in his foot injury, but he wanted to tell the 
readers that this little accident was just a trauma to life. He once said that he never wrote a natural poem, he meant, of course, has never written simply described the nature of poetry. Nature in his poetry is just the background of the human drama, rather than the subject, he can found in the woods, flowers, spring pool the symbols which indicating human living conditions, but he never mysteriously or romantically equate the human and nature.

Frost used his body and heart to experience life, put himself on the real life of excitement, doubts, fear and longing for the ideal and desire expansion, and completely exposed all of these in front of the reader to create many poems with profound meaning. Although he did not expect his views to be a truth, his philosophy become a guide to others, a guide to action, but he is telling people a variety of philosophies.

Discover the beauty of life. In commercial society, under the attack of the consumerism, materialism ideological trend, and the guidance of developing economy slogan, people's spiritual world is dominated by money and interest, the care and protection for beauty are often ignored, people are losing the real aesthetic ability, even produce ugliness in the name of beauty. For example, the transplantation of ancient trees is common in many domestic big cities. Those transplanted trees lost their original vitality, many trees are gradually dying, or have been dead. Planting trees in the city is to beautify the living environment of people, but this kind of transplantation cause actually a kind of ecological disaster [4].

In Frost's poetry, he placed nature and man at an equal position and opposed anthropocentrism. Anthropocentrism is human chauvinism. Human chauvinism believes that man is the king of all things and the source of value. This view is rooted in our culture. However, Frost believed that man was not the king of all things, that man and nature were equal, and that man should have compassion and reverence for other objects in nature. To put human beings in the right position of nature, we can live in a peaceful state of mind, and we can find every bit of beauty in trivial everyday.

"The Tuft of Flowers" was an early poem by Frost, which was published in 1915 as the popular poetry anthology "A Boy's Will". Compared with other widely read Frost's poetry, the domestic scholars pay little attention on the poem, and related studies are rare. The poem tells a farm work experience in the form of a farm worker's inner monologue. One morning, the worker went to dry the newly mown grass, and there was no man on the farm, and the workers who had harvested the herbage had already left. He felt lonely, suddenly saw a tuft of flowers other workers left, his heart suddenly got inspiration, and the loneliness disappeared.

But he turned first, and led my eye to look

At a tall tuft of flowers beside a brook,

\section{A leaping tongue of bloom the scythe had spared}

Beside a reedy brook the scythe had bared.

I left my place to know them by their name,

Finding them butterfly-weed when I came.

The mower in the dew had loved them thus,

By leaving them to flourish, not for us,

Nor yet to draw one thought of ours to him,

But from sheer morning gladness at the brim.

Beauty should be treated in a beautiful way, which is the symbolic meaning of the details of the flowers in Frost's poetry. It represents not only an attitude to life, but also an attitude towards nature. "Wild flowers on the grass" is an important symbol of Frost's poetry, symbolizing the modern dilemma of the coexistence of the real interests and the natural beauty. Grass is a farm produce, a feed for cattle and sheep, representing the farmer's economic interests. The wild flowers on the grass symbolize the beauty of nature. How to choose between the two? In Frost's poem flowers lovers are willing to sacrifice at a local real interest and protection of natural beauty. This is a kind of free and 
easy attitude, which embodies a kind of valuable ecological consciousness of "beauty" overweight "thing".

Relationship between people. The industrial revolution brought rich material benefits to the United States, but it also brought about a meager spiritual wasteland. The materialistic pursuit of material wealth has made people gradually lose their emotional ability, become numb and indifferent objects, and the country has become a spiritual wasteland. Frost objectively records the erosion of industrial civilization on human ethical relations, the relationship between parents and children, couples and neighborhood, more and more apathy and alienation status between people in his poetry. He expressed his indignation, sadness and helplessness for the destruction of the rural ecological environment by the industrial revolution [5].

"Out Out" in "Mountain Interval" tells the story of a young boy who dies after his hand is severed by a "buzz-saw". In the lumbering field away from the city "The buzz-saw snarled and rattled in the yard." At dusk, the boy who had done his share of the hard work suddenly lost his hand and died. Industrial civilization not only deprives the children of fresh life, but also makes the living people lose their emotional ability and become a cold object. For these people, meaning of life is lost in the modern industrial civilization of efficiency and practice, and people's life can be extinguished at any time like a candle.

In addition to depicting the destruction of children by industrial civilization, Frost's poetry also reflects the cold and distorted relationship between husband and wife in the spiritual wasteland. The poet's family is no longer a warm harbor of husband and wife, but barriers they can't break and cut. They cannot understand, trust, and communicate with each other in this hedge. In Frost's view, industrial civilization distorts normal conjugal relations and makes extramarital love a normal phenomenon in modern society. "The fear" in "North of Boston" tells the heroine and the anonymous lover Joel fled to the countryside in order to avoid her husband's tracking. In the dialogue between the two people, readers do not feel the intimate and tacit understanding between lovers, but the estrangement and estrangement between two people. Frost gave a sarcastic irony to those who broke the line of family ethics. He is worried about the loss of husband and wife ethics in modern society. Marriage and extramarital affairs are not the romantic warmth that people crave, but apathy and alienation are the norm.

In the process of industrialization, the relationship between the close family members has been distorted and alienated, so what about the neighborhood? In "Mending Wall”, there are

"He is all pin and I am apple-orchard.

My apple trees will never get across.

\section{And eat the cones under his pines, I tell him.}

He only say, Good fences make good neighbors."

There are so many visible and invisible walls in the human world, and the visible wall is the externalization of the invisible walls of the human mind. Sadly, the visible wall may collapse, and the invisible wall in the human heart is indestructible, symbolizing the barriers and apathy that cannot melt between the human and the industrial world.

How to do make up for the estrangement and apathy of relationships that have been brought about by the healing business? Frost's answer is to go back to nature. He takes the rural as the background of the poems and eulogize the custom and human feelings of harmonious life in the country. Different from the romantic pastoral poet, he regards nature as a symbol in his poetry. He regards nature as a metaphor to explain the relationship between man and nature, man to man, and to personification of nature to repair human relationships and rebuild human spiritual home. The modern industrial civilization has brought about a negative impact on people's apathy, emotional decline, and loneliness in the spiritual wilderness. And nature becomes a broad and deep metaphor, which is the source of strength for the restoration of human relations and the rebuilding of the human mind.

Ideology to Live the Life. Frost considers himself as a realist. He once said: "There are two types of realists: one who offers a good deal of dirt with his potato to show that it is a real one, and the one who is satisfied with the potato brushed clean. I'm inclined to be the second kind. To me, the thing that art 
does for life is to clean it, to strip it to form". (Frost, 1995: 701) He believes that man should not live apart from the society. For the drawbacks in capitalist commercial systems, he maintains a critical attitude, though his responses to those social problems are always subtle, like "a lover's quarrel". His subtleness can be seen in the poem "Precaution", which only had two sentences: "I never dared be radical when young. For fear it would make me conservative when old". And in Frost's most famous poem "The Road Not Taken",

Two roads diverged in a yellow wood,

And sorry I could not travel both

And be one traveler, long I stood

And looked down one as far as I could

To where it bent in the undergrowth;

Then took the other, as just as fair,

And having perhaps the better claim,

Because it was grassy and wanted wear;

Though as for that, the passing there

Had worn them really about the same,

There are two roads in the wood. When facing the question of which way to go, the speaker tries to think carefully to make a decision. Though the reasons that support him to take a road are not sufficient, he prefers the road "grassy and wanted wear".

And both that morning equally lay

In leaves no steps had trodden black.

Oh, I kept the first for another day!

Yet knowing how way leads on to way,

T doubted if $T$ should ever come back

From the inner of the speaker, he wants to take both roads. In that case, he will obtain full understanding of what he wants to explore. But he knows that "way leads on to way", and he cannot come back. As Laotse expresses that things are changing and developing, it's not possible to go back to make a choice again.

I shall be telling this with a sign

Somewhere ages and ages hence:

Two roads diverged in a wood, and I-

I took the one less traveled by,

And that had made all the difference. (131)

From the choice made by the speaker, we can see the speaker is brave to face the challenge that he "took a road less traveled by". While from the aspect of Taoism, the fact that the speaker doesn't take a road more people traveled by signifies his character of non-contention. As Laotse witnessed many injustices and troubles caused by hostilities among people in his time, he advocated the advantages of non-contention. Water is always thought highly of by Laotse, as it approaches all things without contending with them and likes to dwell in the places where nobody likes to stay [2].

\section{Summary}

This article analyzes Frost's poetry from the perspective of spiritual ecology, and expounds the connotation of Frost's poetry from three perspectives: "Discover the beauty of life", "Relationship between people" and "Ideology to Live the Life". Frost used his poetry to tell us that we should fear nature, love nature, and find every bit of beauty in life.Don't be blinded by the fatigue and boredom of life. As for relationship between people, modern industrial civilization has had a negative impact on people after they invaded the countryside. These influences include apathy between people, emotional decline, and loneliness in the spiritual wilderness. Nature has become a broad and deep metaphor, which is the source of strength for the restoration of human relations and the rebuilding of 
the human mind. In the attitude of life, the poet's point of view is similar to that of Laotse. Tell people to be indifferent to fame and gain. I hope that Frost's poetry will become a beacon in our life.

\section{Acknowledgements}

A Planned Program Funded by Philosophy and Social Science Research Program in Heilongjiang (No.: 16WWB01).

\section{References}

[1] Barry E. Robert Frost on Writing.[J]. 1973:188.

[2] GUAN YING. An Interpretation of Robert Frost's Poetry from the Perspective of Taoist Philosophy [D]. Zhengzhou University, 2014.

[3] LI QIN. The Ecological Consciousness in the Poetry of Robert Frost [D]. Suzhou University, 2009.

[4] LI SHICUN. Spiritual ecological interpretation of "The Tuft of Flowers"[J]. Journal of Chongqing Jiaotong University (Social Science Edition), 2013,(04):67-69

[5] CAO RONGRONG, FUXIA, YUYING. From spiritual wasteland to spiritual home -Interpretation of Frost's rural Poetry [J]. Journal of Karamay, 2011,(03):58-60. 